\title{
An approach for flood hazard modelling and mapping in the medium Valtellina
}

\author{
I. Poretti and M. De Amicis \\ University of Milano-Bicocca, Dept. of Environmental and Territorial Sciences, Piazza della Scienza 1, 20126 Milan, Italy
}

Received: 18 November 2010 - Revised: 2 March 2011 - Accepted: 3 March 2011 - Published: 21 April 2011

\begin{abstract}
In the Lombardy Region, as in many other contexts all over the world, hazard maps do not have a precise legislative confirmation. Despite this, they are necessary to support several institutional activities, and among these, local urban planning. An approach to hazard analysis and mapping that fits the Lombardy Region legislative framework is presented here that introduces a level of experimental modelling, making use of SOBEK 1-D-2-D as a tool for hydrodynamic simulations. A stretch of $17 \mathrm{~km}$ of the Adda river in Valtellina has been modelled, referring to twelve scenarios characterised by different temporal probabilities, and comprising the main sources of uncertainty. The results were compared with available local hydraulic studies, and combined to obtain two complementary flood hazard maps which could usefully support urban planning. Advantages and drawbacks of this modelling approach, together with considerations related to flood hazard mapping are discussed.
\end{abstract}

\section{Introduction}

The management and governance of mountain areas has to deal with the presence of multiple natural hazards, which range from rock falls, wide and slow mass movements, very fast earth-debris flows on the slopes to floods on floodplains, alluvial fans or minor tributary valleys; these are in general referred to as "hydrogeological disruptions" (Luino, 2005).

Safety needs for people, buildings and infrastructure often clash with the fact that human settlements have been established on high hazard areas, such as alluvial fans, slopes prone to rock falls and plains subject to floods since ancient times. Therefore, urban planning should find a trade-off for the development of these areas, which are often exploited

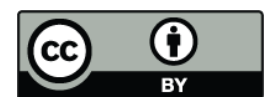

Correspondence to: I. Poretti

(ilaria.poretti@gmail.com) for tourism, agriculture and breeding and the prevention of the negative impacts of natural processes, making use of structural or non-structural measures (Holub and Hübl, 2008; Plate, 2002). This procedure has to be based on a deep understanding of the hazard conditions, described both in spatial and temporal perspective, and should produce information adequate to the needs of end-users (Zerger, 2002; Ferrier and Haque, 2003; Büchele et al., 2006).

Focusing on floods, mountain valleys often suffer from poor investigations of local hazard conditions, or some studies are available but are mainly conducted for engineering purposes.

Flood hazard and risk analysis is necessary, not only to support land use planning, but also for Civil Protection purposes, where the principal aim is to define possible scenarios and supply useful information to organize an operational response. Particularly in this context, a spatially and temporally varying description of hazard is essential (Mens and van der Vat, 2009; Romang and Wilhelm, 2009).

This study aims to provide an approach to analyse flood hazard in an area located in the medium Valtellina, Lombardy Region, crossed by the Adda river, combining institutional directions and experimental modelling.

\subsection{Legislative framework for flood hazard and risk}

In the national legislative framework, river basins are managed by River Basin Authorities (National Law 183/89), organisations where Regions and Local Authorities cooperate to define planning strategies and interventions for the the use and safeguarding of natural resources and the protection against hazards.

The Hydrogeological Basin Plan (called Piano stralcio per l'Assetto Idrogeologico, PAI, 2001) identifies high hazard areas and provides regulations and limitations for land use and development. Its aim is to reduce hydrogeological risk within the basin by directly involving municipalities through the

Published by Copernicus Publications on behalf of the European Geosciences Union. 
compliance of urban planning provisions. Regarding floods, the PAI analyses principal rivers within the pertinence basin and delimits areas where overflow could be expected (these areas are called Fasce Fluviali $A, B, C$ in Italian, from the highest to the lowest degree of hazard) for high discharge events with different return times, supposing interventions proposed for the reduction of risk are realised.

For the Po Basin, these areas are defined by onedimensional numerical modelling and geomorphological considerations based on topographical knowledge available at the time. Within these areas, precise regulations have been established to ensure a satisfying level of safety for humans and holdings, a dynamic equilibrium condition for the river system and a proper space to let the water overflow without causing negative effects in case of flood events. Flood hazard for minor (i.e., torrential) rivers is also identified related to the Municipality it belongs to, even if it is not always delimited, due to the frequent lack of historical pieces of evidences.

Within the Regional Legislative framework, PAI regulations are binding and must be incorporated by Municipalities in their Urban Plan (called Piano di Governo del Territorio, defined by the Lombardy Region with the Regional Law 11/03/2005, n. 12) through a process called "compatibility verification". Municipalities whose Urban Plans are not in compliance with PAI identification and delimitation of hazards should update them with new geological reports and provide new "hydrogeological disruption" maps (D.G.R. 22/12/2005, n. 8/1566).

Due to the regional scale of analysis, the PAI representation of hazard conditions is generally quite coarse. Cross sections for hydraulic simulations for the definition of Fasce Fluviali were surveyed before 2001 and so they cannot take into account topographical changes occurring in the following years, and their spacing is not dense enough to represent local conditions accurately. Nevertheless, all Municipalities can do to increase the level of detail of the representation of flood prone areas is to slightly move the Fasce Fluviali boundaries according to morphological elements which could not have been recognised at a lower scale. New hydraulic studies or simulations are not allowed, and so different water depths or velocities cannot be supposed, nor different discharge values or volumes flowing in the river system. The only exceptions to the rule are when the delimitation of flood prone areas refers to protection measures which still have to be implemented (called Limite di progetto tra Fascia $B$ e $C$, in Italian), and when built-up areas are located in the most hazardous areas (Fasce Fluviali $A$ and $B)$. In these cases, municipalities must conduct a new hazard and risk assessment, following an in-depth study (D.G.R. n. 8/1566, 22/12/2005, Enclosure 4): a new topographic survey has to lead to a new and more detailed one-dimensional hydraulic modelling coupled with geomorphological considerations, following the methodologies reported in two Directives (PAI, Norme di Attuazione, Directives 2 e 4). Resorting to two-dimensional modelling is allowed only for "complex cases" and when dike breaks are expected. These methodologies should be applied also in the case that a municipality, even if in compliance with PAI, proposes an update of its hydrogeological disruption situation, and for an in-depth analysis of hazard conditions for minor rivers.

After defining flood-prone areas, a risk index should be assigned, considering possible damages to people, buildings, infrastructure, the social and economic systems, in order to define possible land uses. If the study allows this more exausting level, risk identification for major rivers should be based on parameters such as probability of overflow, water depths and velocities in the areas contiguous to the river.

\subsection{Flood modelling tools}

The successive step to define flood hazard and subsequently risk conditions is to perform a physically-based hydrodynamic analysis of the river system, based on an input hydrograph. Two main approaches are available (Néelz and Pender, 2009a): one-dimensional (1-D) and two-dimensional (2-D) modelling.

Italian legislation, extensive literature, and common engineering practice suggest making use of 1-D numerical models. In this approach, the river system and floodplain are described and modelled as a unique entity, making use of transversal cross-sections which extend beyond river banks and/or levees, and flow quantities (water depth and velocities) are allowed to vary only in the longitudinal direction, i.e. in case overflow river bed and floodplain share the same water level. This modelling option could be useful and particularly efficient in some particular contexts, e.g. engineering analyses, and mainly for highly artificialised rivers, but it is not the optimal solution under any circumstance, e.g. for banks overflow analysis (Frank et al., 2001; Srinivas et al., 2009).

Another option, which is more common in research than in current practice at the moment, but is becoming more and more popular due to the increasing availability of high resolution Digital Elevation Models (DEMs) of flood prone lands, is 2-D modelling (Tarekegn et al., 2010; David et al., 2009; Alkema, 2007). A DEM with a regular (squared) structured or irregular (triangular) unstructured mesh is used to describe both the river network and the floodplain. Local variations of velocity, water depth and local changes of flow directions can be accounted for. Hence, in case of banks overflow, water movement is described in a more realistic way. This approach is particularly suitable to produce detailed flood hazard maps where flood extent, water depths and flow velocities are reported in a distributed way, as requested by European Union (Directive 2007/60/EC).

Supposing that the flow equations used are not simplified, and that physical processes description is complete. The choice among one of the two modelling options depends mainly on: river morphology (straight/artificial or 


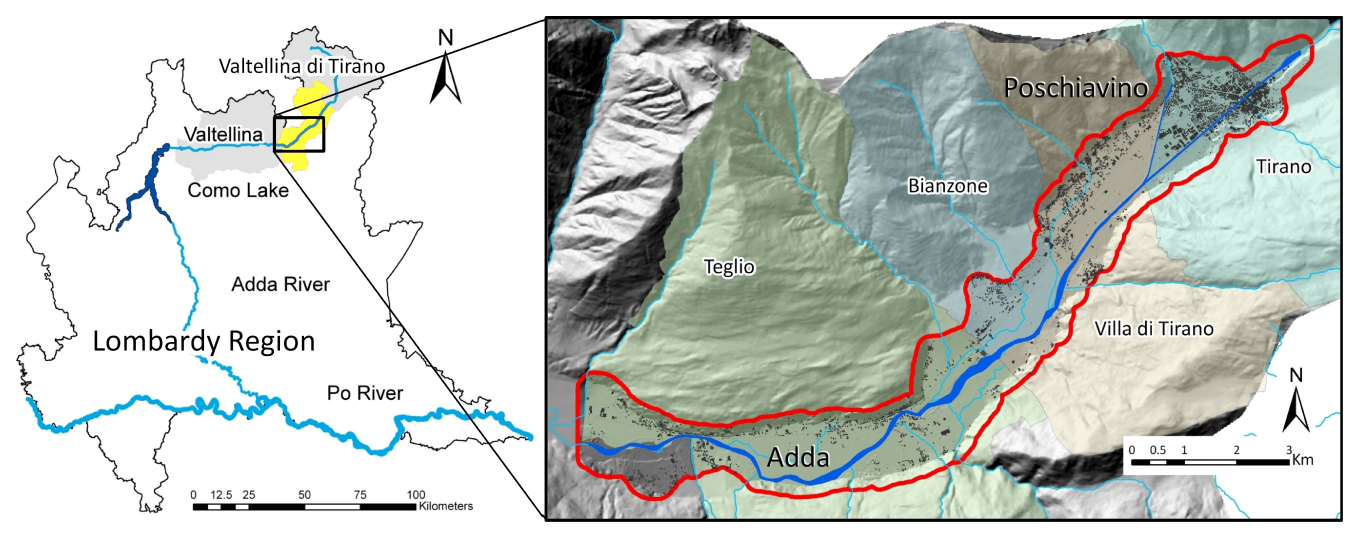

Fig. 1. Location of the study area, the southern part of Valtellina di Tirano in northern Italy, Lombardy Region.

meandering/natural river), data availability and resolution (few cross section data or a very detailed DEM), aim of the study (local or regional scale analysis), and time constraints, since 2-D models have a much higher computational run time than 1-D models. Therefore, it is often quite difficult to make a choice.

A good compromise is 1-D-2-D modelling (Apel et al., 2009; Werner, 2004; Frank et al., 2001): flow in the river bed is modelled in 1-D, while expansion in the floodplain caused by banks overflow is modelled in 2-D. This approach has the advantage of combining the sound knowledge of hydraulic analyses within the river system and the opportunity to model overflows in a realistic way without the need to use very detailed DEMs, i.e., DEM resolution requested by 1D-2-D models is lower than for 2-D ones, and so reducing computational time.

The main difficulties for all the approaches presented above are an accurate representation of topography and a correct setting of roughness parameters, these being the most important pieces of information to implement a hydrodynamic model (Tarekegn et al., 2010; Néelz and Pender, 2009a; Merwade et al., 2008; Horrit and Bates, 2001; Hardy et al., 1999). Moreover, the correctness of these models can often be only qualitatively evaluated, because sufficient data on inundation extent and depths for the calibration and validation phases are lacking (Apel et al., 2009; Werner, 2004). Finally, when applying different modelling approaches, the results could be slightly different (Retallick and Babister, 2008), and this highlights the importance of choosing an approach which is suitable for the case under study.

\section{Study area}

\subsection{General description}

The approach for flood hazard assessment presented in this study applies to an area located in the medium Valtellina (northern Lombardy Region), in the territory of the Moun- tain Consortium of Municipalities (Comunità Montana, in Italian) of Valtellina di Tirano. In particular, it comprises the floodplain area of the Municipalities of Tirano, Villa di Tirano, Bianzone and Teglio (Fig. 1), crossed by the Adda River. Here, steep flanks delimit a quite narrow valley (from $500 \mathrm{~m}$ to $2 \mathrm{~km}$ ), covered by quaternary deposits produced by glacial and subsequently fluvial activity. Elevations of Adda river bed range from 453 to $347 \mathrm{~m}$ a.s.l., with a slope of around $1 \%$ in the upper part and $0.2 \%$ in the lower part of the reach, being $17 \mathrm{~km}$ the total length of Adda reach within the area. Several minor rivers join Adda, flowing from tributary valleys which close in correspondence to alluvial fans and convey sediments in case of severe meteorological events. The main affluent, whose discharge is most significant in case of floods, is the Poschiavino torrent, which originates in the Elvetic territory and joins Adda in Tirano. Where slope is steeper, i.e. in Tirano and Villa di Tirano, Adda is almost completely artificialised, and its width is around $25-30 \mathrm{~m}$. When it leaves urban areas and runs in the fields through orchards and lawns, slope decreases, wide bends appear, and the river width reaches $200 \mathrm{~m}$. Such a morphological heterogeneity, both within the river bed and surrounding floodplain, determines difficulties in the choice of an appropriate hydrodynamic modelling approach. This issue will be discussed later.

\subsection{Information about past events}

While collecting information about past hydrogeological disruptions in the study area (see also Blahut et al., 2011), it was noticed that only a few data are available regarding discharges in case of past flood events, which were quite frequent in the past (7 main events occurred from 1900 to 2000) but has decreased in the last decades (there are no noteworthy events from 2000 till now). This could be related to different meteorological and hydrological conditions, but the main reason should be that after the severe event of 1987 (Luino, 2005), protection measures have been taken and river 
morphology has been redesigned in some areas to ensure a higher level of safety.

From available documents, it seems that the highest discharge ever reached by Adda in Tirano was around $600 \mathrm{~m}^{3} \mathrm{~s}^{-1}$, in 1960 , while the second, around $53 \mathrm{~m}^{3} \mathrm{~s}^{-1}$, was reached during the 1987 flood.

\subsection{Compliance with PAI}

In these areas the Po River PAI identifies a general flood hazard condition for minor rivers, and bounds Fasce Fluviali for the Adda river: in two portions, Fascia $B$ boundary line is " $d i$ progetto", thus, an in-depth hydraulic study is requested. For Teglio, this study was completed in 2007, and for Tirano in 2008.

Three of the four municipalities were not in compliance with PAI provisions, so they had to conduct new geologic studies, completed in 2003. Bianzone was the only complying municipality; however, it provided a geologic update in 2006.

\section{Methodology}

Hazard analysis was performed referring partially to institutional directions (D.G.R. 22/12/2005, n. 8/1566, Enclosure 4) and partially to experimental modelling. PAI discharges and return times (from now on, RT) have been adopted since Adda is bounded by Fasce Fluviali. Available studies were collected and analysed, and a more detailed topographical representation has been produced. Anyway, the choice and application of a particular numerical hydrodynamic scheme is experimental, gathering the opportunity provided by legislation to apply a more than onedimensional analysis when the river network situation is considered complex (D.G.R. 22/12/2005, n. 8/1566, Enclosure 4, Section 3.3).

As described above, the heterogeneity of the Adda river and floodplain did not allow us to make a clear decision regarding what is the most suitable modelling approach to apply. Despite that, the advantages of 1-D-2-D modeling cited above suggested chosing this option.

SOBEK by Deltares (Verwey, 2001) was chosen as the numerical code for modelling. It is a commercial software package that allows multi-dimensional analysis of both river and sewer systems: it is physically based and makes use of complete flow equations (De Saint Venant equations for 1-D modelling, and shallow water equations for 2-D modelling, coupled implicitly). The literature includes several cases in which the software was used proficiently for flood studies (Werner, 2004; Markus et al., 2010; Frank et al., 2001).

\subsection{Data survey}

Besides all the information provided by PAI, available documents and reports were collected and critically analysed.
It is quite complex to analyse the hydrology of the basin and to define a discharge trend for the Adda river system in Valtellina, because it is strongly influenced by drawings and inflows determined by the presence of artificial basins exploited for hydroelectric purposes. Several hydrological studies are available for Valtellina, performed in the years following 1987. They all make use of historical discharge data with a low statistical significance, as they are not spatially dense and not very extended in time. Thus, when applying even slightly different methodologies, the results are quite different (peak discharge in Tirano for a 200 years RT event ranges from 400 to $900 \mathrm{~m}^{3} \mathrm{~s}^{-1}$ ). Due to the complexity of the basin hydrology as well, at the moment the wisest solution is to refer, although with uncertainties, to institutional values, i.e. PAI discharges.

Four recent hydraulic studies have been conducted in the study area for engineering purposes or to better analyse portions where flood PAI boundaries were defined as "di progetto" (see explanation in Sect. 1.1). These studies provided useful practical modelling information (river cross sections morphology and flow parameters), but as territorial continuity is missing, the approaches applied are different and discharge data used do not always coincide, Ceonsequently, a more comprehensive study is desirable.

\subsection{Topographical representation}

As stated by many authors, correct topographical representation is one of the key issues of any hydrodynamic analysis, as it brings the model closer to reality allowing water volumes and river conveyance to be correctly modeled (Tarekegn et al., 2010; Néelz and Pender, 2009b; Reese and Smart, 2009).

In order to perform the 1-D-2-D approach, two entities had to be modelled: the river system and the floodplain.

For the former, available cross sections were collected and compared, trying to reduce the discrepancies due to the different sources they come from. They were then interpolated using the ArcGIS tool developed by Merwade (Merwade et al., 2006, 2008), and the result was a 3-D mesh in the channel fitted coordinate system, the $\mathrm{x}$-direction as the one which follows the channel axis and the y-direction as the perpendicular distance (in left and right direction) from this axis.

For the latter, 3-D digital cartography was provided by the Mountain Consortium at a 1:2000 scale, comprehensive in natural morphology (contours and point elevations) and manmade features (elevation of roads, railway and buildings). After correcting several altitudinal errors and discrepancies, these data were integrated with the 3 -D river mesh and, in order to avoid complications and errors caused by the usual grid interpolation methods (Wise, 2000), a complete Triangulated Irregular Network (TIN) for the whole study area was produced. The TIN was then converted into a DEM making use of the nearest neighbour interpolation technique, since SOBEK allows only the use of structured grids for 2-D modelling, at the moment. 
Building heights were not included in the TIN and DEM since at the resolutions applied in the following steps, their representation was considered inappropriate. Moreover, it is more important to correctly represent floodplain line elements that can constrain the extent of flooding (Werner, 2004).

\subsection{Roughness setting}

Roughness setting is as important as topographical representation for hydrodynamic modelling (Haile and Rientjes, 2007; Alkema, 2007; Tarekegn et al., 2010). Roughness parameters enter into flow equations to describe energy dissipation. Reference tables and calculation procedures exist to help in identifying the most suitable values (Chow, 1959; Arcement and Schneider, 1989). Their definition is not an easy task since roughness coefficients depend not only on the resistance encountered by the flow due to the presence of vegetation, sediment or boulders on the riverbed, but also on water depth and, finally,on model dimensionality, i.e. 1-D, 2-D or even 3-D models applied (Morvan et al., 2008). Moreover, roughness parameters are often more the result of a calibration process than of a physical analysis, and they are also used to compensate model approximations; therefore, available values should be used carefully (Horrit and Bates, 2002; Vidal et al., 2007).

Field analysis, application of suggested methodologies, and comparison with values used for previous hydraulic studies, lead to the definition of Manning roughness values ranging from 0.25 to 0.4 for the Adda river, and from 0.03 to 0.05 for the Poschiavino torrent. For the floodplain, values related to land use were adopted (Chow, 1959; Arcement and Schneider, 1989).

\subsection{Input hydrographs}

To reconstruct a likely hydrograph for the Adda upstream conditions in Tirano, two discharge trends were analysed: the first one is a reconstruction of the 1987 event (Magistrato per il Po, 1997), and the second is the result of a geomorphological analysis performed by AIPO (2008). Adda concentration (or lag) time varies among 20 and 40 hours, so a medium value was adopted $(30 \mathrm{~h})$. Considering also the falling limb of the hydrograph, a total of $70 \mathrm{~h}$ were computed to restate discharges to their original ordinary conditions. The peak discharges provided by PAI for the 20, 100 and 200 years RT, are respectively 530,750 and $830 \mathrm{~m}^{3} \mathrm{~s}^{-1}$.

Another hydrological study calculates for Poschiavino a concentration time of $6 \mathrm{~h}$ (Lombardy Region and ANAS S.p.A., 2002). Peak discharges were derived by PAI, corresponding to 106,133 and $145 \mathrm{~m}^{3} \mathrm{~s}^{-1}$, respectively, for the 20, 100 and 200 years RT.

In the absence of sound indications to define a shape, Adda and Poschiavino hydrographs were supposed to be simply triangular; this is also a precautionary assumption, as input volumes will be slightly superior to those in reality.

\subsection{Model set up}

\subsubsection{Model constraints}

When performing a 1-D-2-D modelling with SOBEK, a particular issue has to be accounted for. In order to avoid the double modelling of water volumes and conveyance, a 2-D grid cell should be approximately as wide as the riverbed or wider but not smaller. In the case under analysis, this is undoubtedly a complication, since the Adda width ranges from 25 to $200 \mathrm{~m}$. A possible solution could be to reduce the complete river bed to a "summer bed", assuming that in summer the water level is at a minimum. Adopting this approach, the correct definition of banks could be lost because of the smoothing produced by applying a relatively coarse resolution DEM; therefore, real overflow conditions are not reproduced anymore. Another problem is that moving from narrow to very wide cross sections, the extreme change in the available flow area could produce numerical instabilities and consequent errors and/or a simulation time increase. Hence it was decided that the wisest solution was to operate on the 2-D grid resolution: eight DEMs ranging from 25 to $100 \mathrm{~m}$ resolution were combined and associated with channel segments having almost the same width (Fig. 2). The complete agreement is not possible since in some cases, only a few hundred meters within the channel have a different width, but the total representation is fairly satisfying (Fig. 3 - graph). The disadvantage of this approach is that floodplain detail is lost when the grid resolution is increased and so the representation of inundation process is quite coarse, but an important advantage is that the channel volumes are modelled correctly in the 1-D system.

Another important issue in SOBEK modelling, is that the method of overflowing the 1-D channel has to be defined beforehand, choosing among three options: "no embankments", i.e. overflow occurs when grid cell elevation is reached both in the right and left direction, whatever elevation the river banks have, meaning the omission of the 1-D cross-sectional profile above this elevation; "highest level of embankments", i.e. overflow occurs when the highest bank elevation is reached, both in the left and right direction, without caring that the other bank has a lower elevation; "lowest level of embankments", i.e. the same as before, but considering the lowest bank elevation. Summarising, SOBEK is not able to distinguish among right and left banks to define an overflow condition. None of the abovementioned options is optimal, but the the third one is more acceptable for the case under analysis, with the specification that the first grid cell beyond the highest level bank should have the same elevation of this bank in order not to overestimate overflow conditions. 


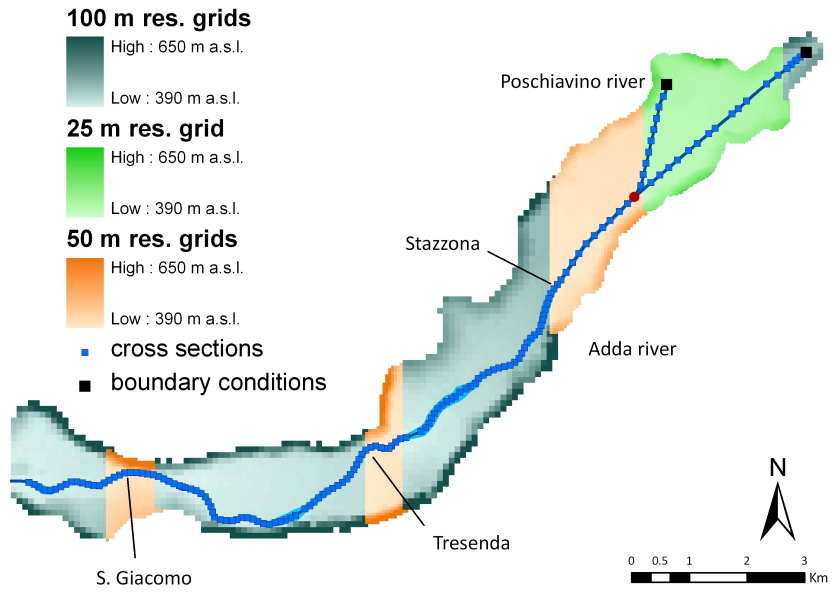

Fig. 2. Combination of the eight different resolution DEMs within the SOBEK 1-D-2-D modelling scheme including the location of boundary conditions and cross sections.

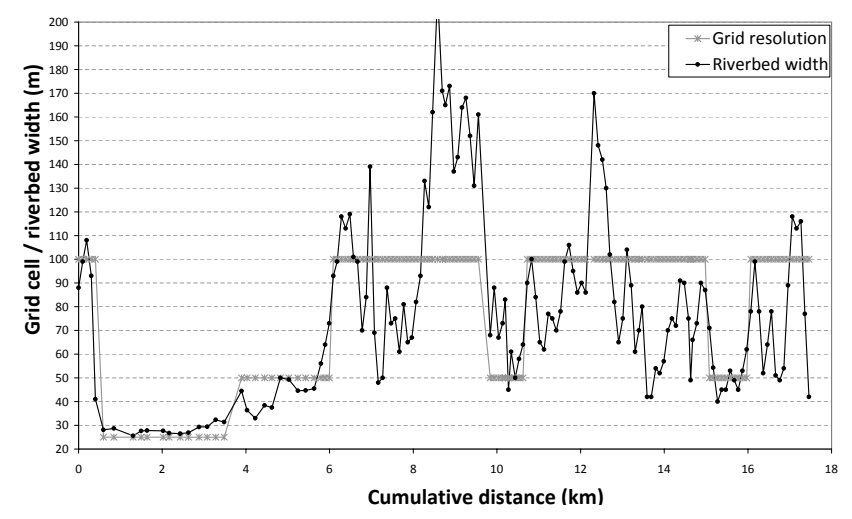

Fig. 3. Relationship among 1-D riverbed width and 2-D grid resolution along the Adda channel.

\subsubsection{Simulations}

Once the topographical setting was defined, two sources of uncertainties had to be considered.

The first one is related to roughness coefficients. Their role in terms of calibration is more limited in higher dimension modelling (Morvan et al., 2008), and therefore attention should be given to channel roughness values (Werner, 2004). Since they can vary within a range, both for physical reasons and as a result of previous hydraulic studies within the study area, two conditions were set: low-ordinary Manning roughness coefficients, equal to maximum 0.03 for Adda and 0.04 for Poschiavino (case a), or higher coefficients, equal to maximum 0.04 and 0.05 for Poschiavino (case b). In this way, it is possible to take into account different river reactions to increasing levels of obstruction within the riverbed, both for the presence of badly maintained vegetation and for possible debris conveyance.
The second one is related to the time of peak of the Adda and Poschiavino hydrographs. Due to the different concentration times of the two basins, the simultaneousness of the peak discharges was quite improbable, but considering the artificiality of the river system, it could not be a priori excluded. So it was supposed that two different extreme situations can occur: the peak time of the two hydrographs was related only to concentration time and Poschiavino reaches its peak before Adda (case 1), or the two peaks were concomitant, so the maximum expected discharge is the sum of the single Adda and Poschiavino peak discharges (case 2).

Considering also three meaningful return times, also institutional reference, i.e. 20,100 and 200 years RT, and intersecting with all the possible situations defined above, a total of twelve scenarios and consequent simulations were set up and run.

\section{Results and discussion}

\subsection{Simulation results}

Analysing SOBEK results, it was observed that moving along the sequence a1-a2-b1-b2, for each return time, an always-increasing intense flood is produced. In order to facilitate the comparison of results, the twelve output grid maps were converted into a single $100 \mathrm{~m}$ resolution map; in this way, some local details were lost but the general pattern of zher affected areas was maintained. Within the floodplain, water depths range from 0 to $4 \mathrm{~m}$, while velocities range from 0 to $3.5 \mathrm{~m} \mathrm{~s}^{-1}$.

Since direct data of past floods are not available, the results were compared with available foregoing hydraulic studies considered reliable. Since they all made use of 200 years RT peak discharges, only the correctness of this event intensity could be evaluated.

For the Municipalities of Tirano and Villa di Tirano, two reports established that overflows are expected both in the right and left directions, from the Poschiavino confluence downstream (Lombardy Region and ANAS S.p.A, 2002; AIPO, 2008), and this is in complete accordance with our results (Fig. 4a). In fact, PAI Fascia $B$ is defined here as "di progetto" i.e. it requires protection measures to be completed. Structural interventions were proposed in 2008, but they are still not complete so a high hazard level is present at the moment, also for low RT floods.

In the territory of the Municipalities of Bianzone and Teglio, the results are in accordance both with another report (Merizzi and Baldini, 2007) and with Fasce PAI (Fig. 4b), except for the fact that our delimitation is wider. This is reasonably due to the fact that our simulations were extended in time and considered the movement of water volumes also in the floodplain. 

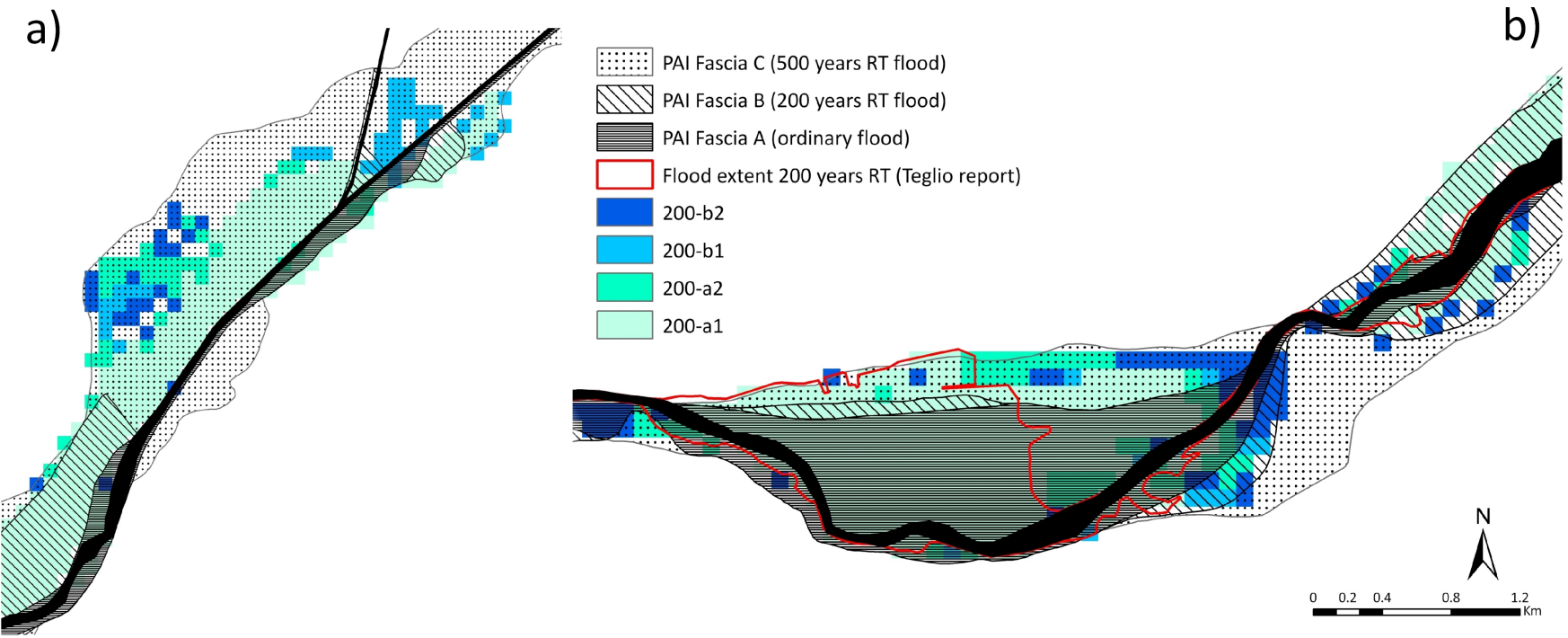

Fig. 4. Visual comparison among modelling results, available hydraulic reports, and PAI Fasce Fluviali in Tirano (a) and Teglio (b), for the 200 years RT flood.

Other parameter maps have been obtained, i.e. time to flood, permanence of water, time to reach maximum water depths and velocities, but they seem to have more importance for flood disaster and emergency planning than for urban planning (David et al., 2009).

The choice to apply a SOBEK integrated 1-D-2-D approach has proved to be useful and appropriate to the aim of the analysis. However, some drawbacks must be highlighted. The relationship among riverbed width and grid cell dimension is a critical issue. From the experience gathered in this study, it seems that the best way to operate is to analyse riverbed morphology trying to reduce its width as much as possible without losing the definition of the main overflowing banks. The choice of grid resolution is a second step, since the 2-D system will have to be adapted to the 1-D system. The use of different resolution grids requires some care in joining them in the modelling phase and some extra time to combine the results, but it turned out to be a good expedient to ensure a correct 1-D-2-D coupling. A drawback is that were grid resolution lower, a lot of floodplain detail would be lost. Hence, a check should be done to ensure that significant elevations are observed and if they are not, single grid cell values should be modified. It follows that the definition of water depths and velocities has a degree of uncertainty which increases as the resolution decreases (i.e. grid cell becomes bigger), in particular, the use of a relatively coarse grid with respect to the width of the channel could result in a significant overestimation of stages (Werner, 2004). If enough spatial detail and high computational performance is allowed, it is to be hoped that full 2-D modelling will solve this limitations.

\subsection{Hazard mapping}

From a scientific point of view, a hazard map should comprise both a spatial and temporal description of the expected dynamic process modelled. In the particular case of flood modelling, the map has to show where and when overflow conditions could happen, referring to events with a defined probability of occurrence; it should also show which areas could be inundated (estimating water levels and velocities), and how long the water is expected to remain in the system (David et al., 2009). Simpler concepts are often adopted for territorial applications, due to their more practical derivation (see Retallick and Babister, 2008). For urban planning, as an example, it could be sufficient to define for different return times which areas could be invaded by flow, and what would water levels and/or velocities be, in order to estimate possible damages. In almost flat areas, i.e. the Adda floodplain in the study area, water depth could be an adequate parameter to describe intensity. The production of hazard maps is not a trivial task, since uncertainties should be included and information provided should be appropriate to end-users' needs. Moreover, different hazard concepts may turn out in different hazard maps; despite that, it is opinion of the authors that the final ranking of the most critical areas should be comparable. An approach is proposed which includes the production of two complementary flood hazard maps.

\subsubsection{Flood hazard map 1}

The first map is a polygon map. Areas affected by inundation have been delimitated for the twelve scenarios, producing a series of polygons. For each RT, a probability index (sevPI) 


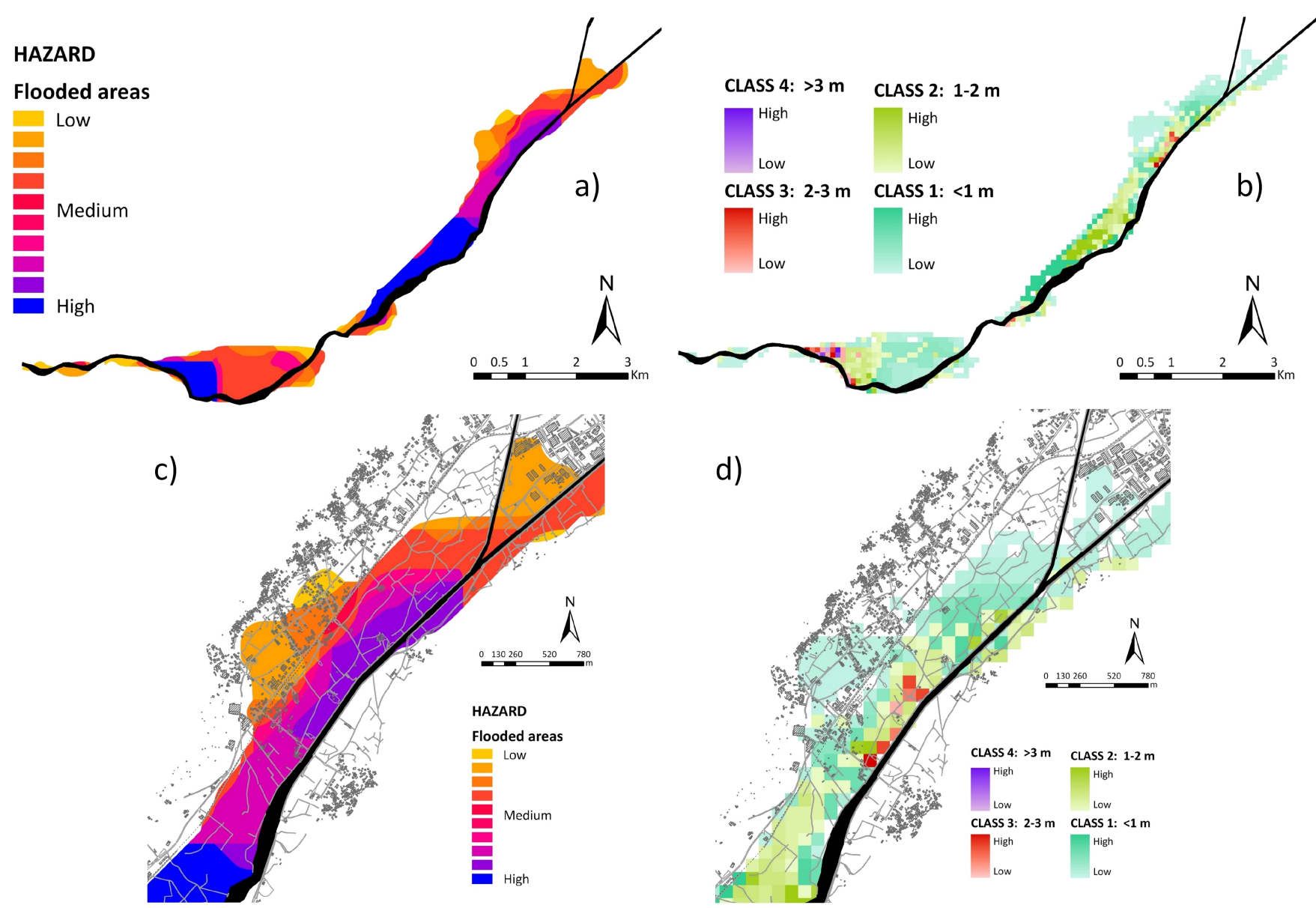

Fig. 5. Representation of flood hazard Map 1 (a) and Map 2 (b), with details (c-d).

of $1,0.75,0.5$ and 0.25 was attributed respectively to the subscenarios a1, a2, b1 and b2, taking into consideration their increasing intensity, or "severity". A probability index (PI) is then assigned to each RT as:

$$
\begin{aligned}
\mathrm{PI}_{\mathrm{RT}} & =\operatorname{sevPI}_{\mathrm{a} 1} \cdot \mathrm{RT}^{-1}+\operatorname{sevPI}_{\mathrm{a} 2} \cdot \mathrm{RT}^{-1}+\operatorname{sevPI} \mathrm{I}_{\mathrm{b}} \cdot \mathrm{RT}^{-1} \\
& +\operatorname{sevPI}_{\mathrm{b} 2} \cdot \mathrm{RT}^{-1}
\end{aligned}
$$

Then, the maximum value among the three RT was assumed as the final probability index $\left(\mathrm{FPI}_{1}\right)$ :

$\mathrm{FPI}_{1}=\max \left(\mathrm{PI}_{20}, \mathrm{PI}_{100}, \mathrm{PI}_{200}\right)$

These values are then attributed to the areas resulting from the intersection of the affected areas polygons for the twelve scenarios. The resulting map is reported in Fig. 5a. Its aim is to show where water is expected to arrive in case of floods of different RT, considering modelling uncertainties expressed by the four sub-scenarios.

\subsubsection{Flood hazard map 2}

The second map has a raster basis. It makes use of both the presence of inundation and the expected water depth in each cell of the grids derived by SOBEK simulations converted into a common $100 \mathrm{~m}$ resolution. For each cell, a value has been assigned which represents a water depth class: (1) for water depths less than $1 \mathrm{~m}$; (2) ranging from 1 and $2 \mathrm{~m}$; (3) ranging from 2 and $3 \mathrm{~m}$; (4) more than $3 \mathrm{~m}$. This will be also the classes of the final hazard map, since the aim is to provide an index of probability that a certain class of intensity (expressed as water depth) is expected within a single cell, considering the temporal probability (RT) and the spatial probability (presence of water in the four subscenarios a1, a2, b1 and b2). Then, a probability index (PI) has been assigned to each class in each sub-scenario. This values of PI are summed for each RT (so, 4 values are summed for each RT, representing the probability indexes of each the four sub-scenarios), and finally summed up for each class. Summarising, the final hazard probability index $\left(\mathrm{FPI}_{2}\right)$ for each class is obtained by: 


$$
\begin{aligned}
\mathrm{FPI}_{2, \operatorname{CLASS}(\mathrm{n})} & =\sum_{\mathrm{RT}=20}^{\mathrm{RT}=200} \operatorname{PI}_{\operatorname{CLASS}(\mathrm{n}), \mathrm{a} 1}+\operatorname{PI}_{\mathrm{CLASS}(\mathrm{n}), \mathrm{a} 2} \\
& +\operatorname{PI}_{\operatorname{CLASS}(\mathrm{n}), \mathrm{b} 1}+\operatorname{PI}_{\mathrm{CLASS}(\mathrm{n}), \mathrm{b} 2}
\end{aligned}
$$

where

$\mathrm{PI}_{\mathrm{CLASS}(\mathrm{n}), \mathrm{sub}-\mathrm{scenario}}=0.25 \cdot \mathrm{RT}^{-1}$

The resulting map is reported in Fig. $5 b$.

The first hazard map is useful to visually compare different areas according to their degree of probability of being affected by a flood whose intensity is not explicitly taken into account, but which can be related to some extent to the RT. The second represents an improvement since it includes also the intensity parameter related to water depth. In fact the two maps are complementary. It can be seen from some details in Fig. 5c-d that a high spatial probability for an area in Map 1 does not mean that the expected intensity would be higher that in other areas, since floodplain water depths, as an indicator of intensity, are determined both by discharges within the river system and by local topographical characteristics. Similarly, a low degree of intensity expected from Map 2 could be associated to a high spatial probability index in Map 1. The overall information provided is in compliance with what requested by Regional Legislation: urban development should be allowed on the basis of the estimation of risk, depending on the eventual presence of water and expected water depths and/or velocities (D.G.R. 22/12/2005, n. 8/1566, Enclosure 4). These maps represent a first level of scientific hazard mapping; if necessary, they could be further classified for specific needs.

It is the opinion of the authors that a single flood hazard map could not be sufficient to describe all the information needed by end-users. Moreover, information overload within a single map could undermine its practicality (LAWA, 2006). This approach could be usefully exported to similar contexts and for similar purposes, being extended to comprise more scenarios and include a more rigorous probability estimation process, i.e. Monte Carlo-based techniques, whenever possible.

\section{Conclusions}

In the Lombardy Region, as in many other contexts all over the world, hazard maps do not have a precise legislative confirmation. Despite this, they are necessary to support activities for a range of final users, such as water management agencies, insurances and stakeholders affected by floods. Finally, they are a crucial tool for disaster support and local urban planning (LAWA, 2002).

An approach towards hazard analysis and mapping that fits the Lombardy Region legislative framework has been presented, one that also introduces a level of experimental modelling, making use of SOBEK as a tool for hydrodynamic simulations. Possible modelling options were critically analysed, and the integrated 1-D-2-D approach was adopted to model $17 \mathrm{~km}$ of the Adda river in the southern part of the territory of Valtellina di Tirano, in the northern Alps. Institutional peak discharges (PAI, 2001) for the return times of 20, 100 and 200 years were used to set triangular input hydrographs. A TIN was produced making use of available cross sections, 3-D cartography provided by the Consortium of Mountain Municipalities, and ArcGIS tools. This was then converted into different resolution DEMs. Modelling uncertainties were mainly related to the peak time of hydrographs and roughness parameters. So, four sub-scenarios were created for each return period resulting in twelve final scenarios. Each of them was run with SOBEK 1-D-2-D module, producing results that were compared with previous hydraulic studies, since reliable data about past flood events were not available. 1-D-2-D proved to be a good modelling option for the purpose even if it has some drawbacks, mainly related to the relationship among 1-D and 2-D resolutions and to the loss of detail in floodplain representation compared to full 2-D models.

Considering indexes related to the spatial probability of inundation (presence of water), temporal probability (return time), and intensity (expressed as water depths), two complementary flood hazard maps were created, which represent a useful combined tool to visually understand which areas could be mostly affected by floods and what would be the expected intensities. These maps are an improvement, both on the usual hazard maps which do not include any expression of modelling uncertainties in the final representation, and of the current delimitation of flood prone areas in the territory under analysis (PAI Fasce Fluviali).

The approach presented is an effective method of hazard mapping, which could helpfully support urban planning, also in the prospect of the national application of the European Directive 2007/60.

Acknowledgements. The authors gratefully acknowledge Corrado Camera from the University of Milan, for his valuable methodological suggestions and Giovanni Di Trapani from the Consortium of Mountain Municipalities of Valtellina di Tirano, for his availability and his help in retrieving useful documentation and databases.

Edited by: F. Luino

Reviewed by: two anonymous referees

\section{References}

AIPO (Interregional Agency for the Po river): Lavori di sistemazione della confluenza fiume Adda e torrente Poschiavino nel Comuni di Tirano, Villa di Tirano e Bianzone, Relazione tecnica, 2008 (in Italian).

Alkema, D.: Simulating Floods: on the application of a 2Dhydraullic model for flood risk assessment, Ph.D. thesis, 
International Institute for the Geo-information Science and Earth Observation, Enschede, 2007.

Apel, H., Aronica, G. T., Kreibich, H., and Thieken, A. H.: Flood risk analyses - how detailed do we need to be?, Nat. Hazards, 49, 79-98, 2009.

Arcement, G. J. and Schneider, V. R.: Guide for selecting Manning's roughness coefficients for natural channels and flood plains, U.S. G.P.O. (Washington and Denver, CO), Water Supply Paper 2339, 38 pp., 1989.

Blahut, J., Poretti, I., Sterlacchini, S., and De Amicis, M.: Database of historical Disasters for Civil Protection Purposes, Nat. Hazard, in review, 2011.

Büchele, B., Kreibich, H., Kron, A., Thieken, A., Ihringer, J., Oberle, P., Merz, B., and Nestmann, F.: Flood-risk mapping: contributions towards an enhanced assessment of extreme events and associated risks, Nat. Hazards Earth Syst. Sci., 6, 485-503, doi: 10.5194/nhess-6-485-2006, 2006.

Chow, V. T.: Open channel flow, McGraw-Hill (Ed), 680 pp., 1959.

David, E., Erlich, M. and Masson, A.: Benefits of 2D modelling approach for urban flood management, in: Flood Risk Management: Research and Practice, edited by: Allsop, W., Samuels, P., Harrop, J, and Huntington, S., Taylor and Francis Group, London, ISBN 978-0-415-48507-4, 2009.

Ferrier, N. and Haque, C. E.: Hazards Risk Assessment Methodology for Emergency Managers: A Standardized Framework for Application, Nat. Hazards, 28, 271-290, 2003.

Frank, E., Ostan, A., Coccato, M., and Stelling, G. S.: Use of an integrated one dimensional-two dimensional hydraulic modelling approach for flood hazard and risk mapping, in: River Basin Management, edited by: Falconer, R. A., Cardiff University, United Kingdom, and Blain, W. R., Wessex Institute of Technology, United Kingdom, 408 pp., 2001.

Haile, A. T. and Rientjes, T. H. M.: Uncertainty issues in hydrodynamic flood modeling, in: Proceedings of the 5th International symposium on Spatial Data Quality SDQ 2007, Modelling qualities in space and time, ITC, Enschede, The Netherlands, 13-15 June 2007.

Hardy, R. J., Bates, P. D., and Anderson, M. G.: The importance of spatial resolution in hydraulic models for floodplain environments, J. Hydrol., 216, 124-136, 1999.

Holub, M. and Hübl, J.: Local protection against mountain hazards - state of the art and future needs, Nat. Hazards Earth Syst. Sci., 8, 81-99, doi:10.5194/nhess-8-81-2008, 2008.

Horrit, M. S. and Bates, P. D.: Effects of spatial resolution on a raster based model of flood flow, J. Hydrol, 253, 239-249, 2001.

Horrit, M. S. and Bates, P. D.: Evaluation of 1D and 2D numerical models for predicting river flood inundation, J. Hydrol., 268, 8799, 2002.

LAWA (German Working Group of the Federal States on Water Issues): Flood hazard map guidelines, available at: www.lawa.de, 2002.

Lombardy Region and ANAS S.p.A.: Progettazione definitiva, comprensiva del quadro progettuale e del quadro ambientale, dello studio di V.I.A. per procedura regionale della SS. 38, variante di Tirano, dallo svincolo di Stazzona (compreso) allo svincolo di Lovero (con collegamento alla dogana di Poschiavo) Relazione idrologica e idraulica, 2002 (in Italian).
Luino, F.: Sequence of instability processes triggered by heavy rainfall in the northern Italy, Geomorphology, 66, 13-39, 2005.

Magistrato per il Po (Ufficio di Cremona): Lavori di adeguamento della sezione di deflusso e consolidamento delle opere spondale in Comune di Tirano, Relazione Idrologica, 1997 (in Italian).

Markus, A. A., Courage, W. M. G., and van Mierlo, M. C. L. M.: A computational framework for flood risk assessment in the Netherlands, Scientific Programming, 18(2), 93-105, doi:10.3233/SPR-2010-0298, 2010.

Mens, M. J. P. and van der Vat, M.: A comparison of evacuation models for flood event management - application on the Schelde and Thames Estuaries, in: Flood Risk Management: Research and Practice, edited by: Allsop, W., Samuels, P., Harrop, J., and Huntington, S., Taylor and Francis Group, London, ISBN 978-0415-48507-4, 2009.

Merizzi, G. and Baldini, D.: Studio idraulico e geologico finalizzato al tracciamento delle fasce fluviali alla scala dello strumento urbanistico comunale e alla ridefinizione delle norme geologiche all'interno della fascia fluviale C, Relazione idrologica e idraulica, 2007 (in Italian).

Merwade, V., Maidment, D. R., and Goff, J. A.: Anisotropic considerations while interpolating river channel bathymetry, J. Hydrol., 331, 731-741, 2006.

Merwade, V., Cook, A., and Coonrod, J.: GIS techniques for creating river terrain models for hydrodynamic modeling and flood inundation mapping, Environ. Modell. Softw., 23, 1330-1311, 2008.

Morvan, H., Knight, D., Wright, N., Tang, X., and Crossley, A.: The concept of roughness in fluvial hydraulics and its formulation in 1D, 2D and 3D numerical simulation models, J. Hydraul. Res., 46(2), 191-208, 2008.

Néelz, S. and Pender, G.: Desktop review of 2D hydraulic modelling packages, Science Report SC080035, Joint UK Defra/Environment Agency Flood and Coastal Erosion, Risk Management R\&D Program, 63 pp., 2009a.

Néelz, S. and Pender, G.: Grid resolution dependency in inundation modelling - A case study, in: Flood Risk Management: Research and Practice, edited by: Allsop, W., Samuels, P., Harrop, J., and Huntington, S., Taylor and Francis Group, London, ISBN 978-0415-48507-4, 2009 b.

Plate, E. J.: Flood risk and flood management, J. Hydrol., 267, 2$11,2002$.

Reese, S. and Smart, G.: High resolution inundation modelling as part of a multi-hazard loss modelling tool, in: Flood Risk Management: Research and Practice, edited by: Allsop, W., Samuels, P., Harrop, J, and Huntington, S., Taylor and Francis Group, London, ISBN 978-0-415-48507-4, 2009.

Retallick, M. E. and Babister, M. K.: Comparison of Twodimensional Modelling Approaches Used in Current Practice to Estimate Hydraulic Hazard, 9th National Conference on Hydraulics in Water Engineering: Hydraulics 2008, Darwin, Australia, 2008.

Romang, H. and Wilhelm, C.: Emergency management of flood events in Alpine catchments, in: Flood Risk Management: Research and Practice, edited by: Allsop, W., Samuels, P., Harrop, J, and Huntington, S., Taylor and Francis Group, London, ISBN 978-0-415-48507-4, 2009. 
Srinivas, K., Werner, M., and Wright, N.: Comparing forecast skill of inundation models of differing complexity - The case of Upton upon Severn, in: Flood Risk Management: Research and Practice, edited by: Allsop, W., Samuels, P., Harrop, J, and Huntington, S., Taylor and Francis Group, London, ISBN 978-0-41548507-4, 2009.

Tarekegn, T. H., Haile, A. T., Rijentes, T., Reggiani, P., and Alkema, D.: Assessment of an ASTER-generated DEM for 2D hydrodynamic flood modeling, Int. J. Appl. Earth Obs., 12, 457-465, 2010.

Verwey, A.: Latest developments in floodplain modelling - 1D/2D integration, Conference on Hydraulics in Civil Engineering, Australia, Hobart, 28-30 November 2001.

Vidal, J. P., Moisan, S., Faure, J. B., and Dartus, D.: River model calibration, from guidelines to operational support tools, Environ. Modell. Softw., 22, 1628-1640, 2007.

Werner, M. G. F.: A comparison of flood extent modelling approaches through constraining uncertainties on gauge data, Hydrol. Earth Syst. Sci., 8, 1141-1152, doi:10.5194/hess-8-11412004, 2004.

Wise, S.: Assessing the quality for hydrological applications of digital elevation models derived from contours, Hydrol. Process., 14, 1909-1929, 2000.

Zerger, A.: Examining GIS decision utility for natural hazard risk modelling, Environ. Modell. Softw., 17, 287-294, 2002.

\section{Legislation}

D.G.R. 22/12/2005, n. 8/1566: Criteri ed indirizzi per la definizione della componente geologica, idrogeologica e sismica del Piano di Governo del Territorio, in attuazione dell'art. 57, comma 1, della 1.r. 11 marzo 2005, n. 12, Lombardy Region Decree, 2005 (in Italian).

Directive 2007/60/EC: On the assessment and management of flood risks, European Parliament and the Council of the European Union, 2007.

National Law 183/89: Norme per il riassetto organizzativo e funzionale della difesa del suolo, Italian National Law, 1989 (in Italian).

PAI: Piano stralcio per l'assetto idrogeologico per il bacino idrografico di rilievo nazionale del fiume Po, adopted with: Deliberazione 18/2001, Autorità di Bacino del fiume Po, Parma, available at: http://www.adbpo.it/ on-multi/ADBPO/Home/Pianificazione/Pianistralcioapprovati/ PianostralcioperlAssettoIdrogeologicoPAI/Pianovigente.html, 2001 (in Italian).

Regional Law 11/03/2005, n. 12: Legge per il governo del territorio, Lombardy Region Law, 2005 (in Italian). 